\title{
Detection of Potato mop top virus and Tobacco rattle virus Using a Multiplex Real-Time Fluorescent Reverse-Transcription Polymerase Chain Reaction Assay
}

\author{
R. A. Mumford, K. Walsh, I. Barker, and N. Boonham
}

Central Science Laboratory, Sand Hutton, York, YO41 1LZ, United Kingdom. Accepted for publication 20 January 2000.

\section{ABSTRACT}

Mumford, R. A., Walsh, K., Barker, I., and Boonham, N. 2000. Detection of Potato mop top virus and Tobacco rattle virus using a multiplex realtime fluorescent reverse-transcription polymerase chain reaction assay. Phytopathology 90:448-453.

Tobacco rattle virus (TRV) and Potato mop top virus (PMTV) are important diseases of potato that are difficult to diagnose reliably by visual symptoms. Effective control strategies rely on accurate diagnosis. This paper describes the development of a multiplex assay for the detection of TRV and PMTV directly from potato tubers and leaves by polymerase chain reaction (PCR) combined with in-tube fluorescent product detection (TaqMan). This technology obviates any post-PCR manipulations and has many advantages including reducing contamination risks, eliminating the need for ethidium bromide staining, and removing the time and cost of gel running. The new assay also allows the replacement of the two separate tests (a TRV reverse-transcription-PCR and a PMTV enzyme-linked immunosorbent assay) currently used with a single-tube multiplex format. In addition to greatly simplifying the detection of these two viruses, the multiplex TaqMan assay was also shown to be more sensitive than either of the tests that it replaces, allowing 100- and 10,000-fold increases in sensitivity for TRV and PMTV detection, respectively. The test reliably detected over 40 different isolates of TRV and PMTV obtained from a wide range of different cultivars and geographical locations, including some samples in which existing tests failed to detect virus. The use of an assay of this kind in routine diagnosis helps to speed up and streamline the diagnostic laboratory; in addition, more reliable diagnosis should help in the control of this damaging disease.

Additional keywords: corky ringspot, pomovirus, spraing, tobravirus.
Some viruses seriously affect the quality of potato crops by producing internal or external tuber symptoms. Although these diseases often do not greatly reduce overall yields, they are economically important because they can lead to the rejection of crops destined for either the processing industry or prepacked supermarket trade. One of the most common virus-induced tuber symptoms is spraing (also known as corky ringspot), which is found throughout Europe and North America $(9,15)$, appearing as brown, necrotic arcs or lines found within the tuber flesh. Spraing can be induced by two different viruses, Tobacco rattle virus (TRV; genus Tobravirus) and Potato mop top virus (PMTV; genus Pomovirus) $(2,15)$. Both viruses are soilborne, with Trichodorus and Paratrichodorus spp. nematodes transmitting TRV (19), while PMTV is transmitted by the powdery scab fungus Spongospora subterranea (8). In addition to the differences in vectors, the susceptibility of different potato cultivars to each virus varies greatly and affects the incidence and severity of spraing (13). Hence, virus control, which depends on vector management and the use of resistant or tolerant varieties, can only occur once an accurate diagnosis has been made. However, diagnosis is further complicated by the fact that TRV and PMTV symptoms can be confused with some other tuber problems. First, physiological disorders, in particular internal rust spot, can cause symptoms similar to spraing (2). Second, both TRV and PMTV can also induce external necrotic rings on tubers, which are sometimes seen without any internal symptoms. As a result, it is possible (especially in nontypical cases) to confuse these symptoms with potato tuber necrotic ring disease caused by the tuber

Corresponding author: N. Boonham; E-mail address: n.boonham@csl.gov.uk

Publication no. P-2000-0315-02R

(C) 2000 The American Phytopathological Society necrosis strain of Potato virus $Y$ (PVY-NTN) (10). Again, control relies on the ability to accurately distinguish TRV and PMTV from these other problems, for which different controls are required.

Although the need for accurate diagnosis is obvious, traditionally, reliable methods for detecting PMTV and TRV in tubers have not been readily available. In both cases, standard methods of virus detection including mechanical inoculation, electron microscopy, and enzyme-linked immunosorbent assay (ELISA) using polyclonal antisera have failed to allow reliable detection from potato $(1,21)$. However, recent developments have rectified that situation. The production of PMTV-specific monoclonal antibodies has permitted the development of a reliable ELISA assay (18). For TRV, the situation was further complicated by the existence of NM-type isolates (4) that exist solely as infectious RNA 1 (with no associated proteins) and, as a result, cannot be detected by ELISA. Detection of these isolates, which appear to be the most common type found in potato, has been overcome by the development of reverse-transcription-polymerase chain reaction (RT-PCR) tests for TRV detection $(3,9,14,21)$.

With the exception of certain niche areas (e.g., phytoplasma detection), the adoption of PCR for the routine detection of plant pathogens has been slow. Two major reasons for this are, first, the problem of running gels (particularly for large sample numbers) and, second, the problem of post-PCR manipulations that leave sensitive PCR assays open to the risk of contamination and falsepositive results. Researchers have used a number of methods to obviate the need to run gels, using either colorimetric detection of PCR products on plates (20) or fluorogenic 5'-nuclease assays (TaqMan; PE-Biosystems, Foster City, CA) and post-PCR fluorescent plate reading (16). Both of these methods, although allowing higher throughput by using a microplate format, are heterologous assays and are still prone to problems with contamination. However, using TaqMan chemistry with real-time detection (i.e., detection of 
PCR products during amplification), both of these problems can be alleviated $(5,11)$.

TaqMan chemistry combines a probe (labeled at each end with reporter-quencher dyes and designed to anneal to a sequence internal to the PCR primers) with the 5'-exonuclease activity of Taq polymerase (6). While the probe is intact, fluorescence emitted by the reporter is absorbed by the quencher (fluorescent resonance energy transfer). During amplification, the probe is cleaved, separating the dyes and resulting in the release in fluorescence corresponding to the amount of product amplified. The increase in reporter fluorescence is monitored in real time during amplification using the ABI PRISM 7700 sequence detection system (PE-Biosystems); hence, there are no post-PCR manipulations.

The advantages of the TaqMan system, when applied to the diagnosis of spraing, are that it allows an assay to be set up that permits the sensitive detection of both PMTV and TRV in a single tube, without the need for any post-PCR manipulations. In a routine diagnostic situation, this means that, rather than carrying out both an ELISA and a RT-PCR assay in parallel for each suspect sample, a single combined assay could be performed, halving costs of both reagents and labor. This paper describes the development of such a multiplex TaqMan using samples from the field and compares its performance with the tests currently used for the routine detection of PMTV and TRV.

\section{MATERIALS AND METHODS}

Infected plant material and virus maintenance. PMTV strain $\mathrm{T}$ was provided by L. Torrance (Scottish Crops Research Institute, United Kingdom) and maintained in mechanically infected Nicotiana benthamiana at a controlled temperature of $18^{\circ} \mathrm{C}$ with a $12-\mathrm{h}$ photoperiod. Two Finnish isolates (Fin $2 b$ and Fin $2 d$ ) were provided by T. Rantanen (Agricultural Research Centre, Finland). TRV strain PRN was provided by D. Robinson (Scottish Crops Research Institute) and was maintained in mechanically infected $N$. tabacum under the conditions described above. Additional field isolates of both TRV and PMTV were obtained from leaf and tuber samples sent into the Central Science Laboratory virology diagnostic laboratory.

RNA extraction. RNA was extracted from potato leaves and tubers using a method modified from that of Hughes and Galau (7). All centrifugation steps were carried out in a microfuge at $11,000 \times g$ and $4^{\circ} \mathrm{C}$, unless stated otherwise. Tissue (100 to $200 \mathrm{mg}$ ) was frozen in liquid nitrogen and ground to a fine powder in a polythene bag. To this homogenate, $0.5 \mathrm{ml}$ of grinding buffer $(1.5 \%$ lithium dodecyl sulfate; $200 \mathrm{mM}$ Tris-HCl, $\mathrm{pH} 8.5 ; 10 \mathrm{mM}$ EDTA; $300 \mathrm{mM} \mathrm{NaCl} ; 1.0 \%$ sodium deoxycholate; $1.0 \%$ IGEPAL CA-630 [catalog no. I3021; Sigma, Poole, England]; $10 \mathrm{mM}$ dithiothreitol; and $5 \mathrm{mM}$ thiourea) was added, mixed, and decanted into a $1.5-\mathrm{ml}$ microfuge tube. An equal volume of $6 \mathrm{M} \mathrm{KOAc}(\mathrm{pH} 6.5)$ was added and mixed, and the tube was incubated on ice for $15 \mathrm{~min}$ before centrifugation for $15 \mathrm{~min}$. The supernatant was transferred to a fresh microfuge tube, and an equal volume of $4 \mathrm{M} \mathrm{LiCl}$ was added before incubation at $4{ }^{\circ} \mathrm{C}$ overnight. Following centrifugation for $25 \mathrm{~min}$, the pellet was resuspended in $200 \mu \mathrm{l}$ of TrisEDTA buffer containing $1 \%$ sodium dodecyl sulfate. To this, $100 \mu \mathrm{l}$ of $5 \mathrm{M} \mathrm{NaCl}$ and $300 \mu \mathrm{l}$ of ice cold isopropanol were added and incubated at $-20^{\circ} \mathrm{C}$ for $20 \mathrm{~min}$ before being centrifuged for $10 \mathrm{~min}$.
The supernatant was discarded and pellet washed with $70 \%$ ethanol before repelleting by centrifugation and air drying. Finally, the pellet was resuspended in $50 \mu \mathrm{l}$ of RNase-free water and stored at $-20^{\circ} \mathrm{C}$.

ELISA. ELISA testing for PMTV was carried out using antiserum and protocols obtained from Adgen, Ltd. (catalog no. 1040-05; Edinburgh, United Kingdom).

RT-PCR. RT-PCR for TRV was carried out using a single-tube reaction, as described previously (12), with some minor modifications (the amounts of each primer and Avian myeloblastosis virus (AMV) reverse transcriptase [Promega Corp., Madison, WI] were increased to 30 pmols and 10 units, respectively). The primers used were those described by Robinson (14). RT-PCR was performed on a PE-Biosystems 2400 thermal cycler using cycling conditions as previously described (12).

TaqMan probe and primer design. The sequences of the primers and probes used for virus detection are given in Table 1. Probes and primers were designed within conserved regions of the genome in which information was available (9); for TRV, within the sequence that encodes the $16-\mathrm{kDa}$ protein of RNA 1 and, for PMTV, within the sequence that encodes the coat protein. The probe and primer combinations were designed using Primer Express software (PE-Biosystems). The software most importantly allows accurate melting temperature $\left(T_{m}\right)$ calculations to be made for sets of primers and probes, such that the primers are within a range of 58 to $60^{\circ} \mathrm{C}$ and probes are $10^{\circ} \mathrm{C}$ higher, at 68 to $70^{\circ} \mathrm{C}$, to improve specificity. In addition, the total length of each amplicon should be below 150 base pairs to allow efficient amplification. The $5^{\prime}$ terminal reporter dye used for TRV was VIC (PE-Biosystems) and for PMTV was 6-carboxyfluorescein (FAM). In both cases, the 3' quencher dye tetra-methylcarboxyrhodamine (TAMRA) was used. All probes and primers were supplied by PE-Biosystems.

TaqMan assay. TaqMan reactions were set up in 96-well reaction plates using PCR core reagent kits (PE-Biosystems) following the protocols supplied, but with the addition of 25 units of Moloney murine leukemia virus (M-MLV) reverse transcriptase (Promega Corp.) per reaction. For each reaction, $1 \mu \mathrm{l}$ of RNA extract was added, giving a final volume of $25 \mu \mathrm{l}$. Plates were then cycled at generic system conditions $\left(48^{\circ} \mathrm{C}\right.$ for $30 \mathrm{~min}, 95^{\circ} \mathrm{C}$ for $10 \mathrm{~min}$, and 40 cycles of $60^{\circ} \mathrm{C}$ for $1 \mathrm{~min}$ plus $95^{\circ} \mathrm{C}$ for $15 \mathrm{~s}$ ) within the 7700 Sequence Detection System (PE-Biosystems), using real-time data collection.

TaqMan assay-primer optimization. In order to optimize assay performance, a primer concentration matrix was carried out to calculate the concentration of primers to be used in the assays. The $3 \times 3$ matrix of 50-, 300-, and 900-nM primer concentrations were set up; the difference between each of the concentrations account for a difference of $2^{\circ} \mathrm{C}$ in actual $T_{m}$ of the primer. The concentration of primers for each set was chosen as the lowest concentration that gave the highest normalized reporter fluorescence $\left(\Delta R_{n}\right)$ and the lowest threshold cycle $\left(C_{T}\right)$.

TaqMan assay-primer limitation. To allow efficient detection of a mixture of both targets at a range of dilutions in a multiplex assay, a primer limitation titration was carried out. A range of primer concentrations $(300,250,200,150,100,50$, and $25 \mathrm{nM})$ were carried out, followed by another range of concentrations starting at the point in which $\Delta R_{n}$ reduces and $C_{T}$ increases. The primer concentration selected was the one that gave the lowest $\Delta R_{n}$ but in which the $C_{\mathrm{T}}$ value remained constant.

TABLE 1. Sequence of primers and probes used for the detection of Potato mop top virus (PMTV) and Tobacco rattle virus (TRV)

\begin{tabular}{llc}
\hline Primer/probe $^{\mathrm{a}}$ & \multicolumn{1}{c}{ Sequence 5'-3' } & Amplicon length (bp) \\
\hline PMTV-1948F & GTG ATC AGA TCC GCG TCC TT & 70 \\
PMTV-2017R & CCA CTG CAA AAG AAC CGA TTT C & 70 \\
PMTV-1970* & ACC AGA ACT ACG GTG CCG CGT CG & 70 \\
TRV-1466F & CAT GCT AAC AAA TTG CGA AAG C & 88 \\
TRV-1553R & TAC AGA CAA ACC ATC CAC AAT TAT TTT & 88 \\
TRV-1489* & ACG TGT GAC ACC AAC CAT GTC AGC AAC T & 88 \\
\hline
\end{tabular}

a Asterisk signifies the fluorescent-labeled TaqMan probe in each set. 
Sensitivity comparison between different detection methods. The relative sensitivity of the different detection methods was compared using infected tissue serially diluted in uninfected tissue. In the case of TRV, tissue was prepared and diluted prior to extraction. In the case of PMTV, slices of infected and healthy tissue were quartered and the two opposite quarters were pooled to make two even samples. The samples were ground in the appropriate dilution of extraction buffer, and serial dilutions of infected tissue in healthy tissue were prepared for the two methods. In each case, the methods were compared using the end-point dilution; no theoretical dilutions were taken into account for either test. The neat sample in each case was taken as the infected tuber tissue prepared for the test in question, prior to any dilution.

\section{RESULTS}

Optimization of primer concentrations in the TaqMan assays. Initially, both assays were carried out separately. Primer concentration matrices were carried out for both the TRV assay (Fig. 1A) and the PMTV assay. The optimum primer concentration was found to be $300 \mathrm{nM} / 300 \mathrm{nM}$, in each case, showing that there were no real differences between $T_{m}$ of the primers in either assay.

Optimization of multiplex TaqMan assays. Prior to multiplexing, it was necessary to carry out primer limitation experiments in both assays such that, in the unlikely event of a mixed infection, one assay would not outcompete the other reaction, by using an excess of reagent reaching a very high $\Delta R_{n}$ during the plateau phase of PCR. First, a crude primer limitation experiment was carried out for TRV (Fig. 1B) and PMTV separately, followed

A

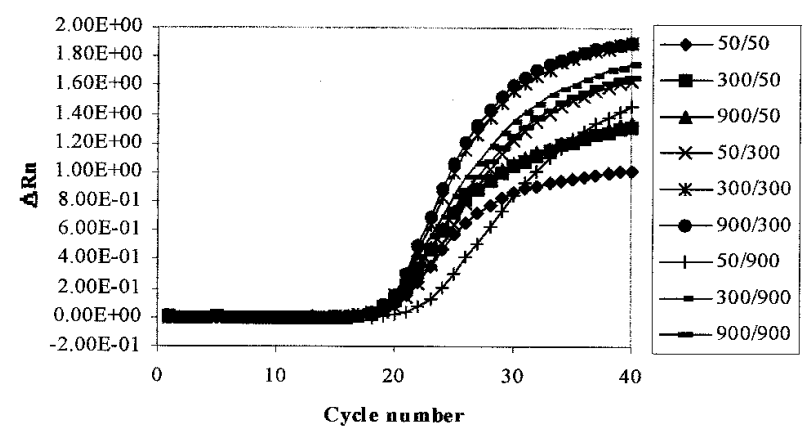

B

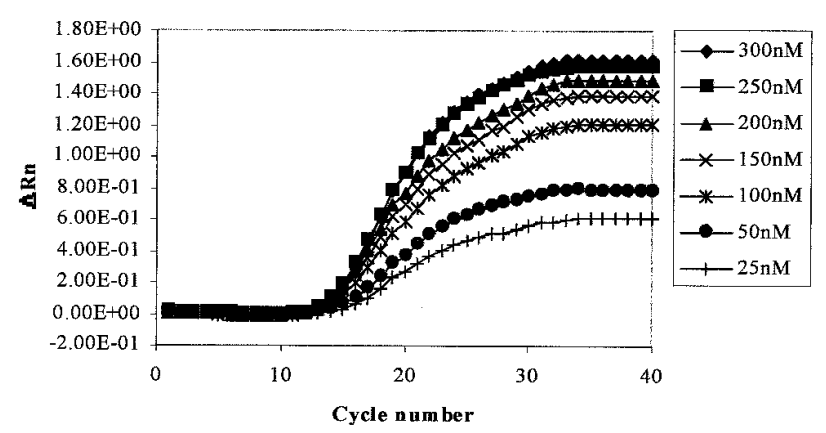

Fig. 1. A, Primer optimization matrix $(3 \times 3)$ for concentrations of primers $(50,300$, and $900 \mathrm{nM})$ illustrating the increase in $C_{T}$ and drop in $\Delta R_{n}$ at low primer concentrations for these primers and an optimum primer concentration of $300 / 300 \mathrm{nM}$, in which the $C_{T}$ is lowest and the $\Delta R_{n}$ highest. B, Primer limitation titration, illustrating a serial dilution of primers from $300 / 300 \mathrm{nM}$ down to $25 / 25 \mathrm{nM}$ and the decreasing $\Delta R_{n}$ as the primer concentration drops to a limiting dilution of $100 / 100 \mathrm{nM}$ followed by an increasing $C_{T}$ below this concentration. by a more specific titration between the primer concentrations in which the $C_{T}$ increased. Primer concentrations of 85 and $175 \mathrm{nM}$ for TRV and PMTV, respectively, were selected as the concentration of primer at which the $\Delta R_{n}$ was lowest without an increase in $C_{T}$. Any further decrease in primer concentration in each case gave a rise in $C_{T}$ and, therefore, a reduction in sensitivity of the assay.

In order to assess if the multiplex assay could detect both viruses in mixed infections across a range of concentrations, dilution series of RNA from tubers infected with each of the viruses were made and mixed together. In this way, assessments could be made to see if low titers of one virus could be detected with high titers of the other, and vice versa. Detection of both viruses was found to be possible across a range of dilutions of the other virus (Fig. 2). At the extremes of virus titer (e.g., high TRV, low PMTV), some increase in the $C_{T}$ value was observed for the low-titer virus, and a linear response was no longer maintained. In addition, loss of detection was observed in the cases of very low titer of one virus with a very high titer of the other virus (in which the lowertiter virus was still detectable in a single infection).

Detection of TRV and PMTV field isolates. A total of 42 samples were tested and, in all cases, the multiplex TaqMan assay was able to detect TRV or PMTV (Table 2). Among these were a type isolate of TRV (strain PRN) and three type isolates of PMTV, one from Scotland (strain T) and two from Finland (strains $2 b$ and 2d). The samples also included 38 field isolates from the United Kingdom taken from either tuber or leaf tissue of 21 different potato cultivars and obtained from a wide range of locations within England, Scotland, and the Isle of Man (Table 2). In all cases, samples were showing symptoms normally associated with either TRV or PMTV. Comparisons of test results between the new multiplex assay and the existing PMTV ELISA or TRV RTPCR show a high degree of correlation, with 38 out of the 42 samples giving identical results. However, in four cases, the TaqMan assay detected isolates that were not detected by the current test (Table 2), including three TRV isolates and one PMTV isolate. In two of these cases (the Slaney and Cara samples from Angus in Scotland), the tubers supplied came from tubers produced from confirmed infected stocks.

Sensitivity comparison between different detection methods. For both viruses, the multiplex TaqMan assay proved more sensitive than either the TRV RT-PCR or PMTV ELISA (Figs. 3 and 4). For TRV, TaqMan was 100 times more sensitive than the RT-PCR test used, with dilution end-points of $1^{-4}$ and $1^{-2}$, respectively (Fig. 3). For PMTV, the sensitivity differential was even greater, with

\section{Dilution of PMTV}

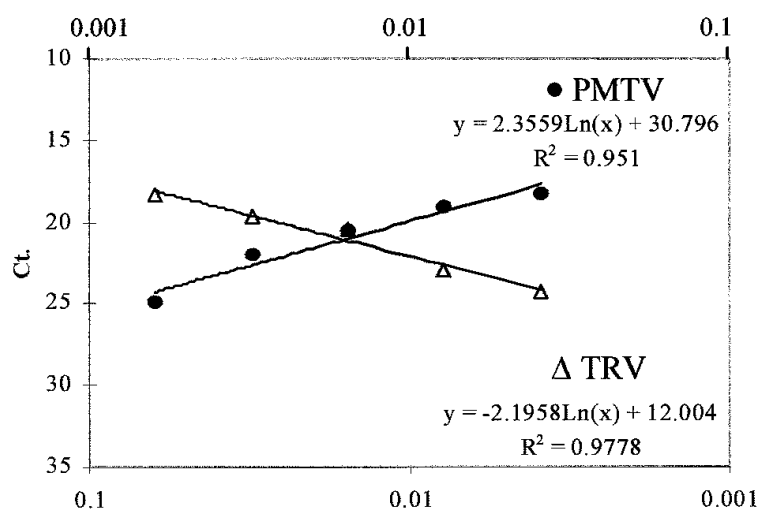

Dilution of TRV

Fig. 2. Dilution of infected tissue versus threshold cycle $\left(C_{T}\right)$ illustrating the detection of both Tobacco rattle virus (TRV) and Potato mop top virus (PMTV) in mixtures. The very high linear correlation for the detection of each virus shows that detection of one virus does not affect the detection of the other virus within this dilution range. 
TaqMan being shown to be 10,000 times more sensitive than ELISA, with dilution end-points equivalent to $1^{-5}$ and $1^{-1}$ for TaqMan and ELISA, respectively (Fig. 4).

\section{DISCUSSION}

The results clearly show that the multiplex TaqMan assay allows the specific and sensitive detection of both TRV and PMTV. The new assay has been tested against a wide range of different type and field isolates (Table 2) obtained from a large number of different geographical locations within the United Kingdom and two locations in Finland. All of the different virus isolates were detected, including isolates of TRV that have deletions in the 16-kDa open reading frame and are identified through the generation of smaller RT-PCR products (14). This demonstrates that the assay has a broad specificity. In addition to being able to detect a broad range of different isolates, the new assay permits detection of virus from both infected tubers and leaf tissue, as well as from a wide variety of different potato cultivars (Table 2). A broad specificity for virus and host are both important considerations if the test is to be used as a routine diagnostic tool.

One of the main advantages of the TaqMan assay is that only one test is required to detect both viruses. Currently, two separate tests are required for the reliable detection of both TRV (RT-PCR) and PMTV (ELISA). This greatly increases the amount of time and labor required to test each sample. ELISA will not work reliably for TRV detection; therefore, streamlining can only be achieved by developing a PMTV test that can use the same RNA preparation used for TRV detection. This has been attempted previously, with the development of a PMTV RT-PCR test (1). However, this test was shown to be less reliable than ELISA (1).

A significant advantage of a real-time TaqMan system is that setting up successful assays is often easier and quicker than for standard PCR. Unlike standard PCR, the primer-probe combinations are designed to work under generic assay and cycling conditions, hence requiring little optimization. In addition, with a standard multiplex PCR, discrimination relies on obtaining products of different sizes that can be distinguished by gel electrophoresis. However, different-sized products amplify with different efficiencies. In contrast, with TaqMan, differentiation can be achieved using different fluorescent dyes and, therefore, products of equal lengths (with equal amplification efficiency) can be used. The fact that multiplexing does not compromise the overall performance of a real-time assay is especially important when detecting mixed infections and, although none were detected in our samples, natural mixtures of TRV and PMTV are known to occur.

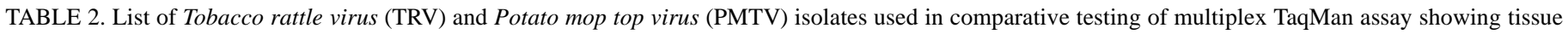
type, source, and test results for the three different detection assays used

\begin{tabular}{|c|c|c|c|c|c|}
\hline \multirow[b]{2}{*}{ Variety $^{\mathrm{a}}$} & \multirow[b]{2}{*}{ Tissue type } & \multicolumn{3}{|c|}{ Test results ${ }^{\mathrm{b}}$} & \multirow[b]{2}{*}{ Source } \\
\hline & & PMTV ELISA & TRV RT-PCR & PMTV-TRV TaqMan & \\
\hline Pepo & Tuber & - & + & $\mathrm{TRV}+$ & North Yorkshire, England \\
\hline Pentland Dell & Tuber & - & + & $\mathrm{TRV}+$ & North Yorkshire, England \\
\hline Nadine & Leaf & + & - & PMTV + & North Yorkshire, England \\
\hline Kennebec & Leaf & + & - & PMTV + & Humberside, England \\
\hline Desiree & Leaf & + & - & $\mathrm{PMTV}+$ & Humberside, England \\
\hline Cara & Tuber & + & - & PMTV + & Hereford and Worcester, England \\
\hline Estima & Leaf & + & NT & PMTV + & North Yorkshire, England \\
\hline Exquana & Leaf & + & NT & PMTV + & North Yorkshire, England \\
\hline Atlantic & Leaf & + & NT & PMTV + & North Yorkshire, England \\
\hline Premiere & Leaf & + & NT & PMTV + & North Yorkshire, England \\
\hline Maris Bard & Leaf & + & NT & PMTV + & Humberside, England \\
\hline Pentland Dell & Tuber & - & + & $\mathrm{TRV}+$ & North Yorkshire, England \\
\hline Cara & Leaf & - & + & $\mathrm{TRV}+$ & Shropshire, England \\
\hline Saturna & Tuber & + & NT & PMTV + & Shropshire, England \\
\hline Maris Bard & Tuber & - & + & $\mathrm{TRV}+$ & North Yorkshire, England \\
\hline Maris Bard & Tuber & - & + & $\mathrm{TRV}+$ & North Yorkshire, England \\
\hline Cycloon & Tuber & - & + & $\mathrm{TRV}+$ & North Yorkshire, England \\
\hline Nicola & Tuber & + & NT & PMTV + & Lincolnshire, England \\
\hline Unknown & Tuber & - & + & $\mathrm{TRV}+$ & Leicestershire, England \\
\hline Cycloon & Tuber & NT & + & $\mathrm{TRV}+$ & North Yorkshire, England \\
\hline Duke of York & Tuber & - & + & $\mathrm{TRV}+$ & Nairn, Scotland \\
\hline Pentland Dell & Tuber & - & + & $\mathrm{TRV}+$ & Norfolk, England \\
\hline Nicola & Tuber & + & - & $\mathrm{PMTV}+$ & Lincolnshire, England \\
\hline Cara & Tuber & + & NT & PMTV + & Angus and NE Fife, Scotland \\
\hline Slaney & Tuber & - & NT & PMTV + & Angus and NE Fife, Scotland \\
\hline Cara & Tuber & + & NT & PMTV + & Angus and NE Fife, Scotland \\
\hline Slaney & Tuber & + & NT & PMTV + & Angus and NE Fife, Scotland \\
\hline Nicola & Tuber & + & NT & PMTV + & Angus and NE Fife, Scotland \\
\hline Slaney & Tuber & + & NT & PMTV + & Angus and NE Fife, Scotland \\
\hline Cara & Tuber & NT & - & $\mathrm{TRV}+$ & Angus and NE Fife, Scotland \\
\hline Maris Peer & Tuber & NT & + & $\mathrm{TRV}+$ & Angus and NE Fife, Scotland \\
\hline Marfona & Tuber & - & + & $\mathrm{TRV}+$ & North Yorkshire, England \\
\hline Unnamed & Tuber & - & + & $\mathrm{TRV}+$ & Peebleshire, Scotland \\
\hline Estima & Tuber & NT & + & $\mathrm{TRV}+$ & Cambridgeshire, England \\
\hline Nicola & Tuber & - & - & $\mathrm{TRV}+$ & Isle of Man \\
\hline Ambo & Tuber & - & - & $\mathrm{TRV}+$ & Isle of Man \\
\hline Navan & Tuber & - & + & $\mathrm{TRV}+$ & Isle of Man \\
\hline Maris Peer & Tuber & - & + & $\mathrm{TRV}+$ & Cambridgeshire, England \\
\hline TRV-PRN & Leaf & NT & + & $\mathrm{TRV}+$ & Type isolate ex-SCRI \\
\hline PMTV-T & Leaf & + & NT & PMTV + & Type isolate ex-SCRI \\
\hline PMTV-Fin2b & Leaf & + & NT & $\mathrm{PMTV}+$ & Type isolate ex-ARC, Finland \\
\hline PMTV-Fin2d & Leaf & + & NT & $\mathrm{PMTV}+$ & Type isolate ex-ARC, Finland \\
\hline
\end{tabular}

a The first 38 samples listed are field isolates and the rest are type isolates.

${ }^{\mathrm{b}}$ ELISA = enzyme-linked immunosorbent assay; RT-PCR = reverse-transcription-polymerase chain reaction; $+=$ positive $;-=$ negative $;$ and NT = not tested. 
A further substantial advantage of a real-time assay when compared with any assay relying on product accumulation $(16,20)$ is that the early cycles of PCR can be recorded $\left(C_{T}\right)$, and very subtle changes in detection (i.e., changes in $C_{T}$ ) can be monitored independently of the plateau effect. This is illustrated by the sensitivity comparisons between a real-time and an end-point PCR assay, reported here for TRV detection. In the real-time assay, as the target RNA concentration drops, a decrease in $\Delta R_{n}$ (i.e., less product accumulation) is also observed. As detection occurs through the generation of a $C_{T}$ value, however, virus detection is unaffected by this lower $\Delta R_{n}$ (Fig. 3B). With end-point assays, the overall sensitivity is lower simply due to reduced product accumulation, as shown with the standard RT-PCR. This reduction in sensitivity would be seen for any method relying on post-PCR product evaluation, regardless of whether TaqMan chemistry was used or not.

A

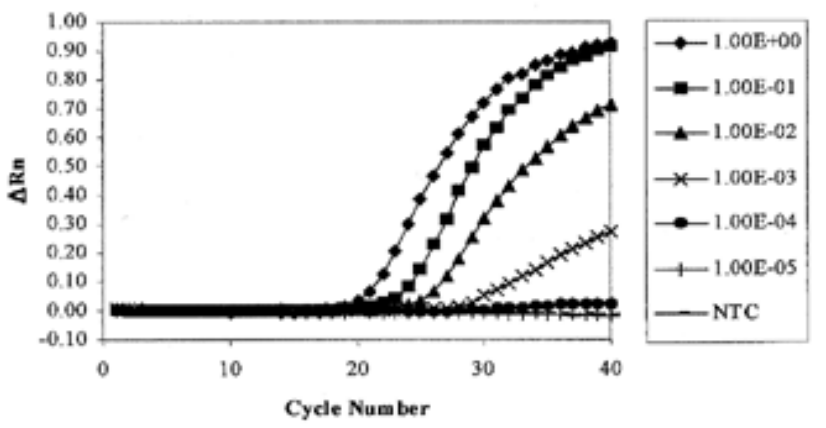

B

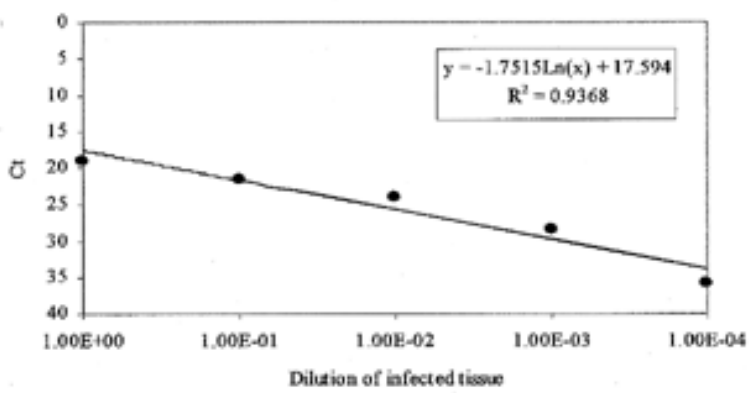

C

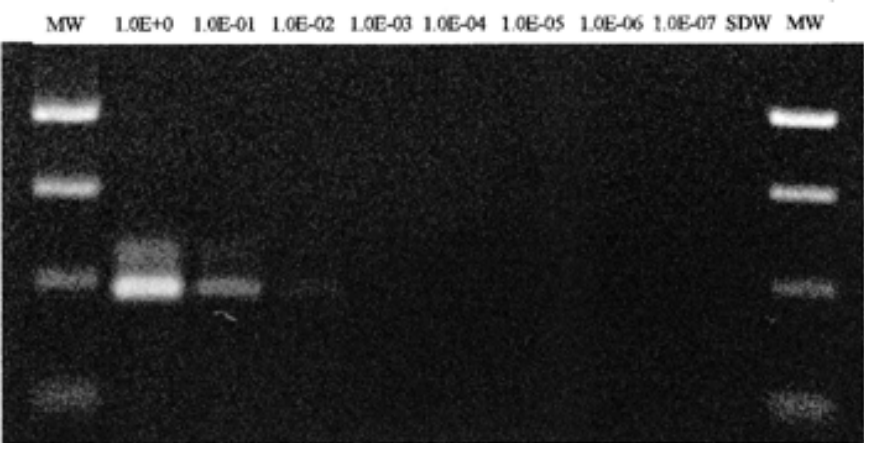

Fig. 3. Sensitivity comparison using a dilution series of infected tuber tissue in healthy tuber tissue between the multiplex TaqMan assay and a reversetranscription-polymerase chain reaction (RT-PCR) for the detection of Tobacco rattle virus (TRV). A, Amplification plots from the 7700 sequence-detection system showing cycle number versus normalized fluorescent values $\left(\Delta R_{n}\right)$, illustrating the detection of TRV in a $1^{-4}$ dilution of infected tissue. B, Plot of weight of infected tissue versus threshold cycle $\left(C_{T}\right)$ illustrating the dynamic range of real-time PCR. $\mathbf{C}$, Gel photo illustrating the detection of TRV in a $1^{-2}$ dilution of infected tissue using traditional RT-PCR.
Our results show that the TaqMan assay is much more sensitive than either of the tests it replaces. Without using purified virus, absolute sensitivity cannot be ascertained; however, the results demonstrate that the relative increases in sensitivity were 10,000 and 100 times when compared with the PMTV ELISA and TRV RT-PCR, respectively (Figs. 1 and 2). In addition, the comparison of methods shows that for both TRV and PMTV there are isolates in each case that are detectable only by TaqMan (Table 2). It is not clear if this is a result of the increase in sensitivity or a problem with PCR inhibitors (in the case of TRV RT-PCR) or if the TaqMan assay

A

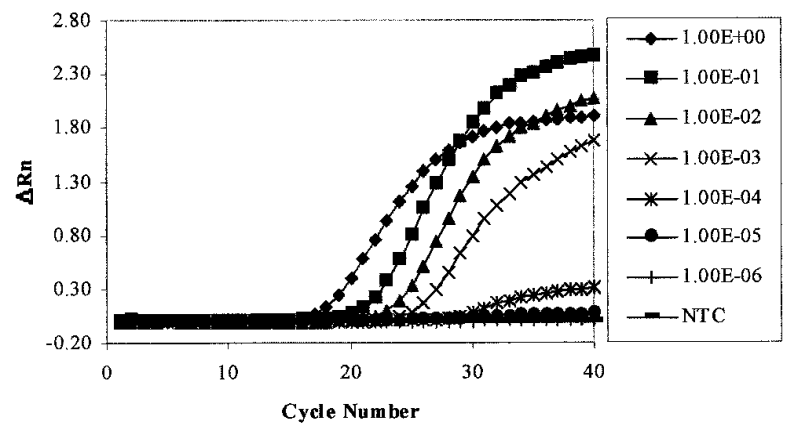

B

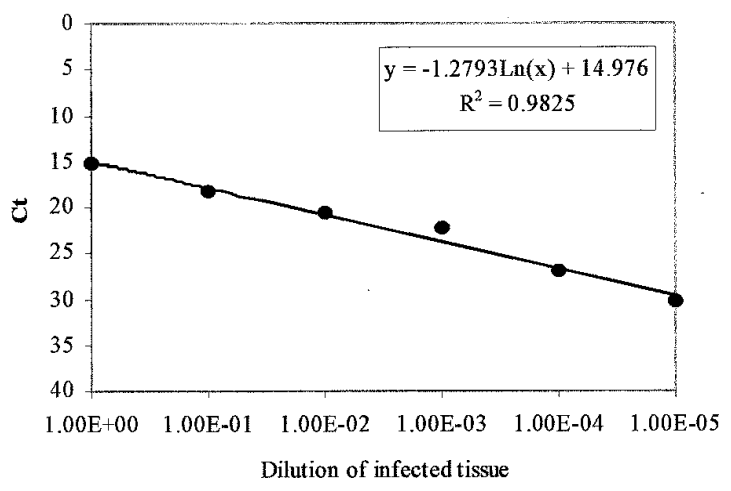

$\mathrm{C}$

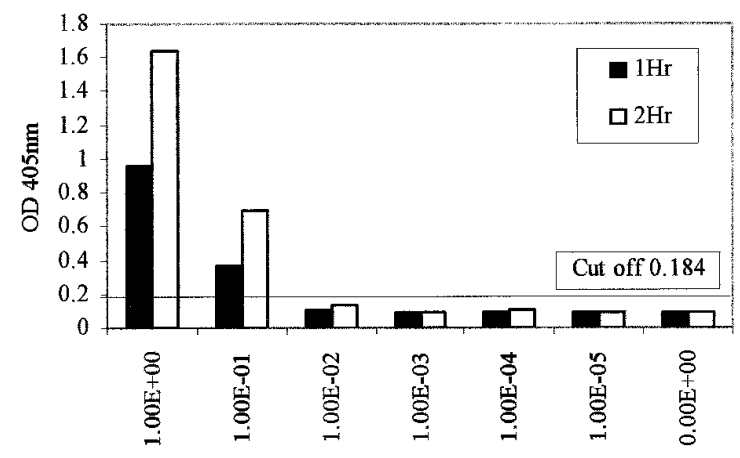

Dilution of infected tissue

Fig. 4. Sensitivity comparison using a dilution series of infected tuber tissue in healthy tuber tissue between the multiplex TaqMan assay and the enzymelinked immunosorbent assay (ELISA) for the detection of Potato mop top virus (PMTV). A, Amplification plots from the 7700 sequence-detection system showing cycle number versus normalized fluorescent values $\left(\Delta R_{n}\right)$ and illustrating the detection of PMTV in a $1^{-5}$ dilution of infected tissue. $\mathbf{B}$, Plot showing dilution of infected tissue versus threshold cycle $\left(C_{T}\right)$ illustrating the dynamic range of real-time polymerase chain reaction. $\mathbf{C}$, Histogram showing dilution of infected tissue versus $A_{405 \mathrm{~nm}}$ (after 1 and $2 \mathrm{~h}$ ) illustrating the detection of PMTV in a $1^{-1}$ dilution of infected tissue by ELISA. 
has a broader specificity than the other methods. There are also sampling problems associated with detecting these viruses, because the distribution of virus within infected tubers is known to be highly uneven $(1,3)$. In light of this, the significant increase in sensitivity of TaqMan over the other tests means that fewer infected cells need to be sampled to give a positive result, greatly reducing the risk of a false-negative result.

Although the detection of virus from asymptomatic tissue is possible, sampling directly from symptomatic tissue is advantageous because the presence of virus can be guaranteed in the host cells adjacent to the necrotic tissue. This can cause problems, however, because symptomatic tissue contains much higher levels of PCR inhibitors such as chlorogenic acid (17). Real-time PCR is less affected by these inhibitors than is standard PCR, because they have a greater effect in the late cycles of PCR, which are critical for product accumulation and, therefore, product visualization by gel electrophoresis or plate-based fluorescence-colorimetric detection assays $(16,20)$. In contrast, product accumulation (represented by high $\Delta R_{n}$ values) is not required to give a positive result in realtime assays, because detection is achieved through the generation of a $C_{T}$ value that, by definition, occurs in the early stages of PCR.

In conclusion, the multiplex TaqMan assay described here provides a reliable alternative test for the detection of both TRV and PMTV. Furthermore, the new test is far more convenient than existing PCR-based assays. Currently, very few PCR-based tests are being used routinely for the diagnosis of plant pathogens, predominantly because the time and labor constraints of existing PCR tests mean that other, less-sensitive or -reliable tests are preferred. The use of TaqMan technology, combined with the introduction of rapid, mass-scale extraction methods, would undoubtedly lead to a rapid expansion in the routine use of PCR.

\section{ACKNOWLEDGMENTS}

This work was carried out under funding from the Plant Health Division of the Ministry of Agriculture, Food and Fisheries (United Kingdom). We thank D. Howells from PE-Biosystems (United Kingdom) for technical support and advice.

\section{LITERATURE CITED}

1. Arli Sokmen, M., Barker, H., and Torrance, L. 1998. Factors affecting the detection of potato mop-top virus in potato tubers and improvement of test procedures for more reliable assays. Ann. Appl. Biol. 133:55-63.

2. Calvert, E. C., and Harrison, B. D. 1966. Potato mop-top, a soil-borne virus. Plant Pathol. 15:134-139.

3. Crosslin, J. M., and Thomas, P. E. 1995. Detection of tobacco rattle virus in tubers exhibiting symptoms of corky ringspot by polymerase chain reaction. Am. Potato J. 72:605-609.

4. Harrison, B. D., and Robinson, D. J. 1978. The tobraviruses. Adv. Virus Res. 23:25-77.

5. Heid, C. A., Stevens, J., Livak, K. J., and Williams, P. M. 1996. Real time quantitative PCR. Genome Res. 6:986-994.

6. Holland, P. M., Abramson, R. D., Watson, R., and Gelfand, D. H. 1991. Detection of specific polymerase chain reaction product by utilizing the $5^{\prime}$ to $3^{\prime}$ exonuclease activity of Thermus aquaticus DNA polymerase. Proc. Natl. Acad. Sci. U.S.A. 88:7276-7280.

7. Hughes, D. W., and Galau, G. 1988. Preparation of RNA from cotton leaves and pollen. Plant Mol. Biol. Rep. 6:253-257.

8. Jones, R. A. C., and Harrison, B. D. 1969. The behavior of potato moptop virus in soil, and evidence for its transmission by Spongospora subterranea (Wallr.) Lagerh. Ann. Appl. Biol. 63:1-17.

9. Kawchuk, L. M., Lynch, D. R., Leggett, F. L., Howard, R. J., and McDonald, J. G. 1997. Detection and characterization of a Canadian tobacco rattle isolate using a PCR-based assay. Can. J. Plant Pathol. 19:101-105.

10. Le Romancer, M., Kerlan, C., and Nedellec, M. 1994. Biological characterization of various geographical isolates of potato virus $\mathrm{Y}$ inducing superficial necrosis on potato tubers. Plant Pathol. 43:138-144.

11. Lie, Y. S., and Petropoulus, C. J. 1998. Advances in quantitative PCR technology: 5' nuclease assays. Curr. Opin. Biotechnol. 9:43-48.

12. Mumford, R. A., and Seal, S. E. 1997. Rapid single-tube immunocapture RT-PCR for the detection of two yam potyviruses. J. Virol. Methods 69: 73-79.

13. National Institute of Agricultural Botany. 1998. Potato Variety Handbook. NIAB, Cambridge.

14. Robinson, D. J. 1992. Detection of tobacco rattle virus by reverse transcription and polymerase chain reaction. J. Virol. Methods 40:57-66.

15. Robinson, D. J., and Harrison, B. D. 1989. Tobacco rattle virus. AAB Descriptions of Plant Viruses, No. 346. Commonw. Mycol. Inst./Assoc. Appl. Biol., London.

16. Schoen, C. D., Knorr, D., and Leone, G. 1996. Detection of potato leafroll virus in dormant potato tubers by immunocapture and a fluorogenic 5' nuclease RT-PCR assay. Phytopathology 86:993-999.

17. Singh, R. P., Singh, M., and King, R. R. 1998. Use of citric acid for neutralizing polymerase chain reaction inhibition by chlorogenic acid in potato extracts. J. Virol. Methods 74:231-235.

18. Torrance, L., Cowan, G. H., and Pereira, L. G. 1993. Monoclonal antibodies specific for potato mop-top virus and some properties of the coat protein. Ann. Appl. Biol. 122:311-322.

19. Van Hoof, H. A. 1968. Transmission of tobacco rattle virus by Trichodorus species. Nematologica 14:20-24.

20. Weekes, R. J., Barker, I., and Wood, K. R. 1996. An RT-PCR test for the detection of tomato spotted wilt tospovirus incorporating immunocapture and colorimetric estimation. J. Phytopathol. 144:575-580.

21. Weidemann, H. L. 1995. Detection of tobacco rattle virus in potato tubers and roots by polymerase chain reaction. J. Phytopathol. 143:455-458. 